\title{
Influence of current density and temperature in the zinc electroplating process at sulfate-based acid solution: study on process efficiency and coating morphology
}

Influência da densidade de corrente e da temperatura no processo de eletrodeposição de zinco em solução ácida à base de sulfato: estudo da eficiência do processo e da morfologia do revestimento

\author{
G. A. C. Gonçalves ${ }^{1 *}$; P. M. S. Campos'; T. C. Veloso ${ }^{3}$; V. R. Capelossi ${ }^{1}$ \\ ${ }^{l}$ Science, Innovation, and Modeling in Materials Postgraduate Program, Department of Exact and Technological \\ Sciences, State University of Santa Cruz, 45662-900, Ilhéus-BA, Brazil \\ ${ }^{2}$ Interdicisplinary Bachelor of Science, Techno-Science and Innovation Training Center, Federal University of \\ Southern Bahia, 45613-204, Itabuna-BA, Brazil \\ ${ }^{3}$ Techno-Science and Innovation Training Center, Federal University of Southern Bahia, 45613-204, Itabuna-BA, \\ Brazil
}

*gabriel.abelha.carrijo@gmail.com

(Received on June 01, 2021; accepted on October 13, 2021)

\begin{abstract}
Zinc as a metallic coating is a common strategy to protect the carbon steel against corrosion. The most common process of zinc deposition is known as electroplating. Because of the high toxicity of cyanidebased baths, the interest in acid baths has grown, but they present many challenges to be overcome. Several operational parameters and bath constitution - such as current density, $\mathrm{pH}$, and zinc concentration - can impact the current efficiency, deposit quality, and coating morphology. In this work, the process efficiency and the coating morphology were evaluated on electroplated AISI 1008 carbon steel samples. The current density and temperature were individually varied on a range from $7.5 \mathrm{~mA} . \mathrm{cm}^{-2}$ to $30.5 \mathrm{~mA} . \mathrm{cm}^{-2}$, and from $40{ }^{\circ} \mathrm{C}$ to $60{ }^{\circ} \mathrm{C}$, respectively. The process efficiency was evaluated by current efficiency $\left(e_{C}\right)$. The surface morphology was analyzed by both optical microscopy (OM) and scanning electron microscopy (SEM). Varying the bath temperature did not promote impacts in the current efficiency, which remained in all temperatures evaluated over $95 \%$. On the other hand, increasing the current density, increased the current efficiency, starting from $(85 \pm 2) \%$ at $7.5 \mathrm{~mA} . \mathrm{cm}^{-2}$ to $(92 \pm 2) \%$ at $19.0 \mathrm{~mA} \cdot \mathrm{cm}^{-2}$, and $(95 \pm 1) \%$ at $30.5 \mathrm{~mA} . \mathrm{cm}^{-2}$. Through OM and SEM analysis, the increase in the temperature tended to turn the coating rougher, and the sample was not completely covered at $7.5 \mathrm{~mA} . \mathrm{cm}^{-2}$. Therefore, we recommend the use of a temperature between $40{ }^{\circ} \mathrm{C}$ and $50{ }^{\circ} \mathrm{C}$ associated with a current density of $30.5 \mathrm{~mA} . \mathrm{cm}^{-2}$.
\end{abstract}

Keywords: metallic coating, zinc electroplating, current efficiency.

O zinco é utilizado como revestimento metálico em técnica conhecida como eletrogalvanização. Devido à sua toxicidade, os banhos baseados em cianeto caíram em desuso, dando lugar aos banhos ácidos que possuem muitos desafios a serem superados. Muitos parâmetros operacionais e de banho, como densidade de corrente, $\mathrm{pH}$ e concentração de zinco podem afetar a eficiência de corrente, a qualidade do depósito e a morfologia do revestimento. Assim, este trabalho avaliou a eficiência do processo e a morfologia do revestimento sobre as amostras de aço carbono AISI 1008 eletrogalvanizadas. A densidade de corrente e a temperatura foram variadas individualmente na faixa de $7,5 \mathrm{~mA} \cdot \mathrm{cm}^{-2}$ a $30,5 \mathrm{~mA} \cdot \mathrm{cm}^{-2}$ e de $40{ }^{\circ} \mathrm{C}$ a $60{ }^{\circ} \mathrm{C}$, respectivamente. A eficiência do processo foi avaliada por meio da eficiência de corrente $\left(e_{c}\right)$, enquanto que as modificações morfológicas foram estudadas tanto por meio da microscopia óptica (MO) quanto da microscopia eletrônica de varredura (MEV). A temperatura do banho não impactou a $e_{c}$ que se manteve acima de $95 \%$ em todas as temperaturas avaliadas. Por outro lado, o aumento da densidade de corrente promoveu o aumento da $e_{c}$, partindo de $(85 \pm 2) \%$ em 7,5 mA.cm ${ }^{-2}$, atingindo $(92 \pm 2) \%$ em 19,0 mA.cm ${ }^{-2}$ e $(95 \pm 1) \%$ em 30,5 mA.cm-2. Do ponto de vista morfológico, o aumento na temperatura tendeu a aumentar a rugosidade do revestimento, enquanto que as amostras obtidas em $7,5 \mathrm{~mA} \cdot \mathrm{cm}^{-2}$ não foram totalmente recobertas. Portanto, recomenda-se a eletrogalvanização entre as temperaturas $40{ }^{\circ} \mathrm{C}$ e $50{ }^{\circ} \mathrm{C}$ associadas a $30,5 \mathrm{~mA} \cdot \mathrm{cm}^{-2}$.

Palavras-chave: revestimento metálico, eletrogalvanização, eficiência de corrente. 


\section{INTRODUCTION}

Carbon steel is one of the most versatile material due to its good mechanical properties, but they are susceptible to corrosion deterioration $[1,2]$. The corrosion phenomena are a natural and spontaneous process in which the metal returns to its most stable oxidation state [3]. These oxidative reactions can compromise the structural integrity and cause severe damages impacting the economy, environmental, and socio-cultural sectors [4-6].

In this scenario, the use of zinc as a metallic coating is a common strategy to avoid the corrosion deterioration of carbon steel materials [7]. The zinc promotes good galvanic protection, behaving like a sacrificial anode [3]. The zinc oxide also creates a barrier that protects the carbon steel from aggressive environments [8]. Among the galvanizing techniques, the use of zinc electroplating stands out [9-12].

In general, zinc electroplating consists of the zinc reduction reaction on the cathode surface. Thus, this technique is classified as a non-spontaneous process and the use of an external power supply is needed [3]. The cathode and the anode are connected and immersed in an electrolyte solution, which is also called an electroplating bath (Figure 1).

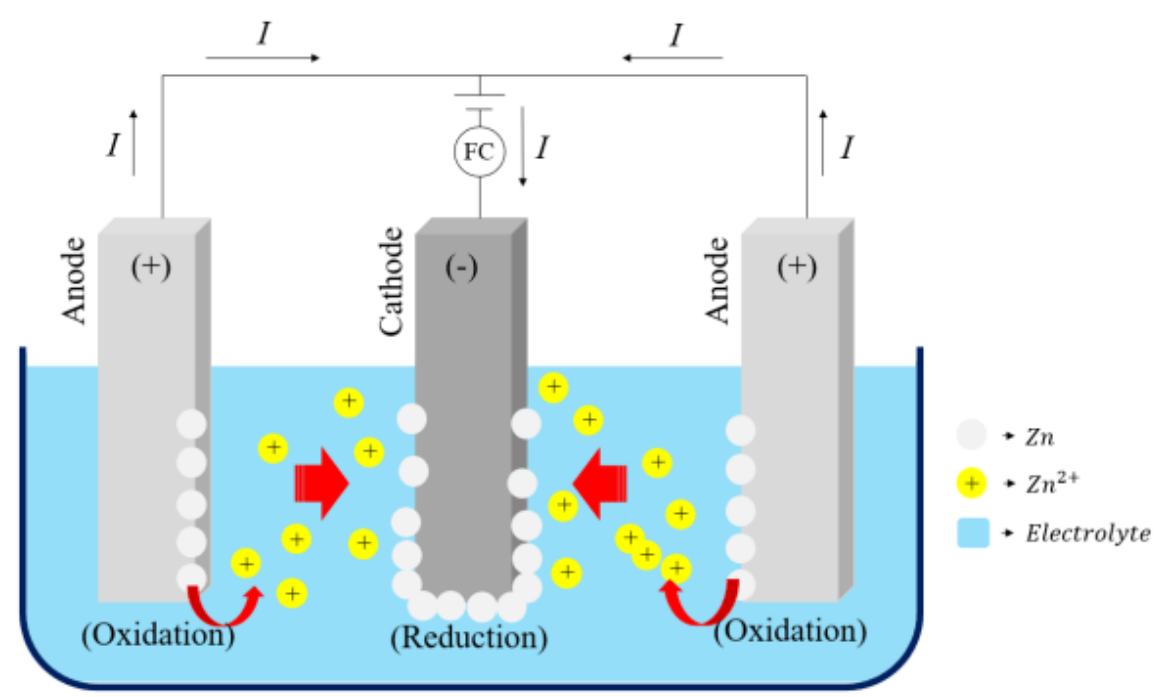

Figure 1: Schematic representation of the zinc electroplating process, consisting of a cathode, one or more anodes, the electrolytic bath, and an external power supply (FC). Adapted from Paunovic and Schlesinger (2006)[12].

There are three main types of zinc electroplating. They can be separated into cyanide-based alkaline baths, non-cyanide-based alkaline baths, and acid baths [10, 13, 14]. Because of the high toxicity of cyanide-based solutions to the environment and operators, they were gradually replaced since the 1970s by non-cyanide-based solutions and acid solutions [10,15]. Currently, acid chloride-based and sulfate-based baths have special prominence. These baths are essentially less toxic, faster, and able to achieve high current efficiency [12, 16, 17].

The electroplating process can be influenced by several operational factors or by bath constitution $[14,18,19]$. The zinc concentration, electroplating time, $\mathrm{pH}$, current density, and bath temperature can influence the process efficiency, the surface morphology, and the zinc grain growth [20-22].

Most reported studies are focused on optimizing the acid baths containing chloride [11, 23] or in the morphology changes caused by additives in the electrolyte bath constitution [18, 24]. Therefore, the process efficiency and the zinc coating morphology on electroplated AISI 1008 carbon steel samples were evaluated in this work. The process took place in an acid sulfate-based solution, while the current density and temperature were individually varied on a range of 7.5 $\mathrm{mA} . \mathrm{cm}^{-2}$ to $30.5 \mathrm{~mA} . \mathrm{cm}^{-2}$, and $40{ }^{\circ} \mathrm{C}$ to $60^{\circ} \mathrm{C}$, respectively. The process efficiency was evaluated by the current efficiency and the surface morphology was performed by optical microscopy (OM). 


\section{EXPERIMENTAL}

\subsection{Electrolyte and apparatus}

The electrolytic cell (Figure 2) consisted of three electrodes, one cathode (AISI 1008 carbon steel) between two anodes (lead plates). The electrodes were spaced at $10 \mathrm{~mm}$ and they had fixed dimensions of $50 \mathrm{~mm} \times 70 \mathrm{~mm} \times 1.2 \mathrm{~mm}$. The cell had its temperature controlled by a water bath, under magnetic stirring of $380 \mathrm{rpm}$.

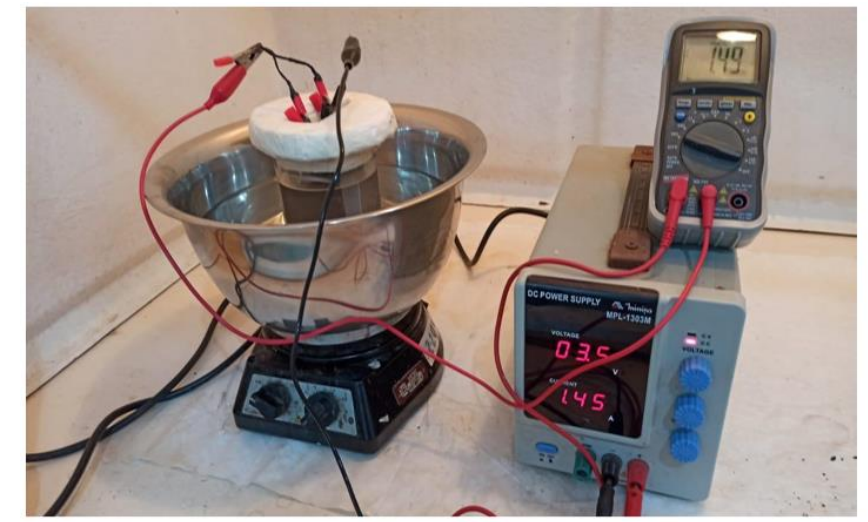

(a)

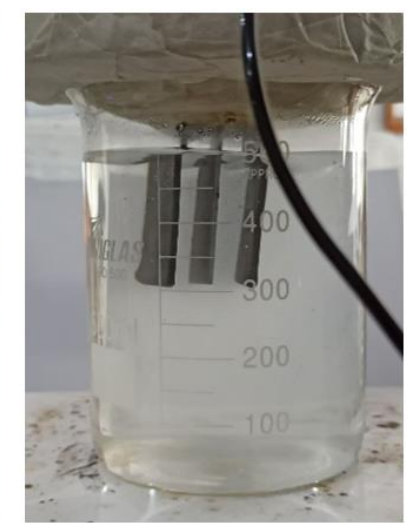

(b)

Figure 2: The electrolytic cell working (a) and the AISI 1008 carbon steel between two lead plates at the zinc electroplating process $(b)$.

The electroplating bath consists of an aqueous solution of $\mathrm{H}_{2} \mathrm{SO}_{4}, \mathrm{Na}_{2} \mathrm{SO}_{4}$, and $\mathrm{Zn}^{2+}$ as summarized in Table 1. All reagents used in the electroplating bath were ACS analytical grade. The process was carried out by the galvanostatic way and the current was supplied by an external power supply (MPL-1303M, Minipa). The current density varied at $7.5 \mathrm{~mA} . \mathrm{cm}^{-2}, 19.0 \mathrm{~mA} . \mathrm{cm}^{-2}$, and $30.5 \mathrm{~mA} . \mathrm{cm}^{-2}$ at a fixed temperature $\left(50{ }^{\circ} \mathrm{C}\right)$. The temperature varied at $40{ }^{\circ} \mathrm{C}, 50{ }^{\circ} \mathrm{C}$, and $60{ }^{\circ} \mathrm{C}$ at a fixed current density $\left(30.5 \mathrm{~mA} \cdot \mathrm{cm}^{-2}\right)$.

Table 1: List of parameters for the zinc electroplating bath to each condition evaluated.

\begin{tabular}{cccc}
\hline & & $\begin{array}{c}\text { Current density } \\
\text { variation }\end{array}$ & $\begin{array}{c}\text { Temperature } \\
\text { variation }\end{array}$ \\
\hline Bath & $\mathrm{Zn}^{2+}\left(\mathrm{g} \cdot \mathrm{L}^{-1}\right)$ & 50 & 50 \\
Parameters & $\mathrm{Na}_{2} \mathrm{SO}_{4}\left(\mathrm{~g} \cdot \mathrm{L}^{-1}\right)$ & 50 & 50 \\
& $\mathrm{pH}$ & 2.5 & 2.5 \\
\hline \multirow{5}{*}{ Operational } & Cathode & AISI 1008 carbon & AISI 1008 carbon \\
Parameters & Anode & steel & Lead plates \\
& $i\left(\mathrm{~mA} \cdot \mathrm{cm}^{-2}\right)$ & $7.5,19.0$, and 30.5 & 30.5 \\
& $\mathrm{~T}\left({ }^{\circ} \mathrm{C}\right)$ & 50 & 40,50, and 60 \\
& $t(\mathrm{~min})$ & 20 & 20 \\
& $\mathrm{Stirrer}(\mathrm{rpm})$ & 380 & 380 \\
\hline
\end{tabular}

$i=$ current density; $\mathrm{T}=$ temperature; $t=$ time.

Thus, the experimental profile consisted of 5 groups. For each group, 5 samples were used, which makes a total of 25 samples analyzed. 


\subsection{Sample surface preparation}

The sample surface was treated before the electroplating process to remove the oil, rust, and dirt. Primarily the substrate was completely immersed in acetone (ACS analytical reagent grade) for $10 \mathrm{~min}$ in an ultrasonic bath (LS-3D, LimpSonic, $40 \mathrm{kHz} / 70 \mathrm{~W})$. Then, the sample was immersed in an alkaline degreaser (50 g.L $\mathrm{L}^{-1}, 680 \mathrm{RM}$, Saloclean) under stirring of $380 \mathrm{rpm}$ at $50{ }^{\circ} \mathrm{C}$ for $10 \mathrm{~min}$. Finally, the substrate was dipped in $\mathrm{H}_{2} \mathrm{SO}_{4}(3 \mathrm{M}$, ACS analytical reagent grade) etching solution for $10 \mathrm{~s}$.

After each washing step, the substrate was rinsed in a distilled water bath for $5 \mathrm{~min}$. After the electroplated process, the substrate was also rinsed in a distilled water bath for 5 min and then dried immediately by a thermal air blower.

\subsection{Electroplating process analysis}

The process analysis consisted of the evaluation of calculated parameters (process efficiency, theoretical thickness of the zinc layer, and surface density of zinc in the coating) and images analysis. The process efficiency was evaluated for each sample by the current efficiency, $e_{C}$, which could be calculated by Equation 1 [13], where $w_{E P}$ and $w_{T}$ are respectively the electroplated zinc weight and the theoretical weight.

$$
e_{c}=\frac{w_{E P}}{w_{T}} \cdot 10^{2}
$$

The $w_{E P}$ was determined by gravimetric analysis of the sample before and after the electroplating process. On the other hand, the $w_{T}$ was calculated using the Faraday Electrolysis Law as expressed in Equation 2 [13], where $M$ is the zinc atomic weight $\left(65.38 \mathrm{~g}^{-\mathrm{mol}^{-1}}\right) ; I$ is the current (A); $t$ is the electroplating process time (s); $n$ is the zinc valency $(n=2)$; and $F$ is the Faraday constant $\left(F=96485.33\right.$ s.A.mol $\left.{ }^{-1}\right)$.

$$
w_{T}=\frac{M \cdot I \cdot t}{n \cdot F}
$$

Based on the theoretical weight of zinc previously mentioned, the theoretical thickness of the zinc layer, $\varphi_{T}$, could be calculated by Equation 3 [13], where $S_{U s e f u l}$ is the useful area $\left(\mathrm{cm}^{2}\right), \rho_{Z n}$ is the zinc density $\left(\rho_{Z n}=7.14 \mathrm{~g} . \mathrm{cm}^{-3}\right)$, and $w_{T}$ is the theoretical weight, which was described in the previous equation.

$$
\varphi_{T}=\frac{w_{T}}{\rho_{Z n} \cdot S_{\text {Useful }}} \cdot 10^{4}
$$

Surface density of zinc in the coating, $\rho_{A}$, - another process parameter of interest - could be calculated based on the electroplated zinc weight $\left(w_{E P}\right)$ and the useful area $\left(S_{\text {Useful }}\right)$ previously mentioned, as described in Equation 4:

$$
\rho_{A}=\frac{w_{E P}}{S_{\text {Useful }}} \cdot 10^{2}
$$

\subsection{Surface morphology analysis}

The thickness of the zinc layer measurements (MP40, Helmut Fischer) was analyzed in both sides of the sample. A total of 6 measurements in each side of the sample were taken and the arithmetic mean thickness of the coating was calculated based on those. While the surface 
morphology characterization was analyzed by images obtained both by optical microscopy (OM, S9, Leica) and by scanning electron microscopy (SEM, VEGA3, Tescan).

\section{RESULTS AND DISCUSSION}

\subsection{Effect on process efficiency}

The process efficiency was calculated employing the Equations 1 and 2. The results to the zinc electroplating process varying the temperature and the current density independently are presented in Table 2.

Table 2: Current efficiency values, $e_{c}$, determined to the zinc electroplating process varying the temperature and the current density independently.

\begin{tabular}{ccc}
\hline & & $\left(\boldsymbol{e}_{\boldsymbol{c}} \pm \boldsymbol{\sigma}_{\boldsymbol{e}_{\boldsymbol{c}}}\right) \%$ \\
\hline \multirow{3}{*}{$(\boldsymbol{T}){ }^{\circ} \boldsymbol{C}$} & $\mathbf{4 0}$ & $98 \pm 2$ \\
& $\mathbf{5 0}$ & $95 \pm 1$ \\
& $\mathbf{6 0}$ & $96 \pm 1$ \\
\hline & $\mathbf{7 . 5}$ & $87 \pm 2$ \\
(i) $\boldsymbol{m A} \cdot \boldsymbol{c m}^{-\mathbf{2}}$ & $\mathbf{1 9 . 0}$ & $92 \pm 2$ \\
& $\mathbf{3 0 . 5}$ & $95 \pm 1$ \\
\hline
\end{tabular}

The temperature variation did not promote statistically relevant impact in the current efficiency, as observed in Table 2 . For the samples obtained at $40{ }^{\circ} \mathrm{C}, 50{ }^{\circ} \mathrm{C}$, and $60{ }^{\circ} \mathrm{C}$ were obtained $(98 \pm 2) \%,(95 \pm 1) \%$, and $(96 \pm 1) \%$ to $e_{c}$, respectively. These results allow classifying the zinc electroplating process under these conditions as efficient [16].

Temperature is directly related to the kinetics of the process. Therefore, as the operating temperature of electrolytic cell increases, both an increase in current efficiency and a decrease in specific energy consumption are observed [13].

Such behavior was also reported to the zinc electro-obtaining process in an acid sulfate medium [14]. The authors observed an increase in the current efficiency as the bath temperature was increased $\left(94.0 \%\right.$ at $25{ }^{\circ} \mathrm{C}$ to $97.7 \%$ at $\left.50{ }^{\circ} \mathrm{C}\right)$. They also observed that both the specific energy consumption $\left(2,960 \mathrm{~kW} \cdot \mathrm{t}^{-1}\right.$ at $25^{\circ} \mathrm{C}$ to $2,700 \mathrm{~kW} \cdot \mathrm{t}^{-1}$ at $\left.50{ }^{\circ} \mathrm{C}\right)$ and the cell voltage $(3.39 \mathrm{~V}$ at $25^{\circ} \mathrm{C}$ to $3.21 \mathrm{~V}$ at $45^{\circ} \mathrm{C}$ ) decreased.

The authors reported an exponential behavior between the current efficiency and the bath temperature. Thus, for values above $50{ }^{\circ} \mathrm{C}$ no significative influence on the current efficiency was observed [14]. These results corroborate with those presented in this paper. As the experimental range was around $50{ }^{\circ} \mathrm{C}$, the samples tended to present the same current efficiency, as indicated in Table 2.

On the other hand, as already reported, electroplating is not a spontaneous process, thus the current is the driving force of this method and directly impact the current density. As much higher is this operational parameter, a greater amount of zinc tended to be reduced on the substrate surface $[14,19,23]$.

In this sense, increasing the current density tended to increase the current efficiency, as observed in Table 2. For the samples electroplated at $7.5 \mathrm{~mA} . \mathrm{cm}^{-2}, 19.0 \mathrm{~mA} \cdot \mathrm{cm}^{-2}$, and $30.5 \mathrm{~mA} . \mathrm{cm}^{-2}$ were obtained $(87 \pm 2) \%,(92 \pm 2) \%$, and $(95 \pm 1) \%$ to $e_{c}$, respectively. These results allow classifying the zinc electroplating process at $19.0 \mathrm{~mA} . \mathrm{cm}^{-2}$ and $30.5 \mathrm{~mA} . \mathrm{cm}^{-2}$ as efficient [16].

Such results are in line with those reported to the zinc electro-obtaining process in an acid sulfate medium [14]. The authors observed that the current density did not impact substantially the current efficiency when a range between $10 \mathrm{~mA} \cdot \mathrm{cm}^{-2}$ and $65 \mathrm{~mA} \cdot \mathrm{cm}^{-2}$ was employed. The authors also observed that both the specific energy consumption $\left(2,440 \mathrm{~kW} \cdot \mathrm{t}^{-1}\right.$ at $10 \mathrm{~mA} \cdot \mathrm{cm}^{-2}$ to 
$2,990 \mathrm{~kW} \cdot \mathrm{t}^{-1}$ at $\left.65 \mathrm{~mA} \cdot \mathrm{cm}^{-2}\right)$ and the cell voltage $\left(2.86 \mathrm{~V}\right.$ at $10 \mathrm{~mA} \cdot \mathrm{cm}^{-2}$ to $3.47 \mathrm{~V}$ at $\left.65 \mathrm{~mA} \cdot \mathrm{cm}^{-2}\right)$ tended to increase as the current density increases [14].

Similar results were also found in a report that studied the zinc electroplating process in an acidified zinc sulfate solution [19]. They observed no dependence of the current efficiency and the current density in a range between $9.5 \mathrm{~mA} . \mathrm{cm}^{-2}$ and $92 \mathrm{~mA} . \mathrm{cm}^{-2}$.

The influence of current density $\left(30 \mathrm{~mA} \cdot \mathrm{cm}^{-2}\right.$ to $\left.60 \mathrm{~mA} \cdot \mathrm{cm}^{-2}\right)$ was also studied in the zinc electroplating process from an acidic sulfate electrolyte with [BMIM] $\mathrm{HSO}_{4}$ as additive [24]. The authors observed that the current density was independent to the current efficiency when individually varied in the process at low temperatures.

All these papers attribute such behavior to the mass transfer resistance being negligible in these operational conditions [14, 19, 24].

\subsection{Effect on the surface morphology}

The surface density of zinc in the coating, $\rho_{A}$, and the theoretical thickness of the zinc layer, $\varphi_{T}$, were calculated respectively employing the Equations 3 and 4 . Both calculated parameters and thickness measurements to the zinc electroplating samples varying the temperature and the current density independently are presented in Table 3.

Table 3: Surface density and layer thickness of the zinc coating obtained varying the temperature and the current density independently.

\begin{tabular}{ccccc}
\hline & & $\left(\boldsymbol{\rho}_{\boldsymbol{A}} \pm \boldsymbol{\sigma}_{\boldsymbol{\rho}_{A}}\right) \boldsymbol{g} \cdot \boldsymbol{m}^{-\mathbf{2}}$ & $\left(\boldsymbol{\varphi}_{T} \pm \boldsymbol{\sigma}_{\varphi_{T}}\right) \boldsymbol{\mu m}$ & $\left(\boldsymbol{\varphi} \pm \boldsymbol{\sigma}_{\varphi}\right) \boldsymbol{\mu m}$ \\
\hline & $\mathbf{4 0}$ & $122 \pm 4$ & $18.3 \pm 0.3$ & $20.9 \pm 0.2$ \\
$(\boldsymbol{T}){ }^{\circ} \boldsymbol{C}$ & $\mathbf{5 0}$ & $119 \pm 4$ & $17.5 \pm 0.8$ & $27.2 \pm 0.7$ \\
& $\mathbf{6 0}$ & $115 \pm 5$ & $17.4 \pm 0.8$ & $25.5 \pm 0.9$ \\
\hline & $\mathbf{7 . 5}$ & $22 \pm 1$ & $3.9 \pm 0.5$ & $8.7 \pm 0.7$ \\
$(\boldsymbol{i}) \boldsymbol{m} \boldsymbol{A} . \mathbf{c m}^{-\mathbf{2}}$ & $\mathbf{1 9 . 0}$ & $69 \pm 1$ & $10.7 \pm 0.5$ & $21.3 \pm 0.5$ \\
& $\mathbf{3 0 . 5}$ & $119 \pm 4$ & $17.5 \pm 0.8$ & $27.2 \pm 0.7$
\end{tabular}

$\rho_{A}=$ surface density of zinc in the coating; $\varphi_{T}=$ theoretical thickness of the zinc layer; $\varphi=$ arithmetic mean thickness of the zinc layer.

The temperature did not promote huge changes in the amount of zinc deposited in the coating, as seen in the current efficiency analysis. Then, increasing the temperature did not promote statistically relevant impact in the surface density of zinc in the coating, as observed in Table 3. For the samples electroplated at $40{ }^{\circ} \mathrm{C}, 50{ }^{\circ} \mathrm{C}$, and $60{ }^{\circ} \mathrm{C}$ were obtained $(122 \pm 4) \mathrm{g} \cdot \mathrm{m}^{-2}$, $(119 \pm 4)$ g.m ${ }^{-2}$, and $(115 \pm 5)$ g.m $\mathrm{m}^{-2}$ to $\rho_{A}$, respectively.

The same was reflected in the calculation of the theoretical thickness of the zinc layer, which did not show statistically relevant differences: $(18.3 \pm 0.3) \mu \mathrm{m},(17.5 \pm 0.8) \mu \mathrm{m}$, and (17.4 \pm 0.8$) \mu \mathrm{m}$ to $40{ }^{\circ} \mathrm{C}, 50{ }^{\circ} \mathrm{C}$, and $60^{\circ} \mathrm{C}$, respectively. These values, however, are lower than those obtained in the arithmetic mean thickness of the coating performed on the samples: $(20.9 \pm 0.2) \mu \mathrm{m},(27.2 \pm 0.7) \mu \mathrm{m}$, and $(25.5 \pm 0.9) \mu \mathrm{m}$ to $40{ }^{\circ} \mathrm{C}, 50{ }^{\circ} \mathrm{C}$, and $60{ }^{\circ} \mathrm{C}$, respectively.

The sample obtained at $40{ }^{\circ} \mathrm{C}$ had a arithmetic mean thickness closest to the theoretical thickness, while the samples obtained at $50{ }^{\circ} \mathrm{C}$ and $60{ }^{\circ} \mathrm{C}$ had a higher and similar thickness value. Such behavior suggests that the samples obtained at the lowest temperature tended to present a thinner, compact, dense and possibly more homogeneous coating, as it presented the smallest standard deviation.

On the other hand, the current density impacts directly the amount of zinc that is deposited in the coating, as presented in Equation 4, behavior similarly observed in the current efficiency analysis. In this sense, increasing the current density tended to increase the surface density of zinc in the coating, as shown in Table 3. For the samples electroplated at $7.5 \mathrm{~mA} . \mathrm{cm}^{-2}, 19.0 \mathrm{~mA} . \mathrm{cm}^{-2}$, and $30.5 \mathrm{~mA} . \mathrm{cm}^{-2}$ were obtained $(22 \pm 1) \mathrm{g} \cdot \mathrm{m}^{-2},(69 \pm 1) \mathrm{g} \cdot \mathrm{m}^{-2}$, and $(119 \pm 4) \mathrm{g} \cdot \mathrm{m}^{-2}$ to $\rho_{A}$, respectively. 
As expected, increasing the current density tended to increase the arithmetic mean thickness of the coating: $(8.7 \pm 0.7) \mu \mathrm{m},(21.3 \pm 0.5) \mu \mathrm{m}$, and $(27.2 \pm 0.7) \mu \mathrm{m}$ to $7.5 \mathrm{~mA} . \mathrm{cm}^{-2}$, $19.0 \mathrm{~mA} . \mathrm{cm}^{-2}$, and $30.5 \mathrm{~mA} . \mathrm{cm}^{-2}$, respectively. These values are higher and followed the same tendency of the theoretical thickness calculated: $(3.9 \pm 0.5) \mu \mathrm{m},(10.7 \pm 0.5) \mu \mathrm{m}$, and $(17.5 \pm 0.8) \mu \mathrm{m}$ to $7.5 \mathrm{~mA} . \mathrm{cm}^{-2}, 19.0 \mathrm{~mA} . \mathrm{cm}^{-2}$, and $30.5 \mathrm{~mA} . \mathrm{cm}^{-2}$, respectively.

The difference in the coating thickness between the arithmetic mean thickness value and the calculated value employing the Equation 3 was observed both in the temperature and the current density variations. The calculated value for the theorical thickness takes into account the homogeneous distribution of zinc over the entire substrate area immersed in the electroplating bath, but this behavior is not actually observed $[3,12]$.

In reality, the coating thickness is not regular in all points in the substrate. Essentially, the driving force of the electroplating process is the current supplied by an external source, but the current is not equally distributed over the entire surface area. As result, the current density varies from point to point, tending to be concentrated at the substrate edges, corners, and protruding points $[3,12]$.

This behavior is due to the electric field formed and, by definition, depends on the voltage and the distance between the electrodes. In this sense, the local electric field is more intense in the edges and protruding points than in recesses, vias and cavities [12]. Therefore, the coating thickness tends to be higher on the edges than in the substrate center [3], resulting in the behavior shown in Table 3.

\subsection{Surface characterization}

The samples right after the electroplating process are shown in Figure 3. Through them it is already possible to notice that the temperature variation resulted in the complete covering in all samples (Figure 3a, 3b, and 3c). On the other hand, the current density variation presented points where the substrate was exposed at $7.5 \mathrm{~mA} \cdot \mathrm{cm}^{-2}$ (Figure 3d). This figure also makes evident the preferential behavior of the local electric field, which the edges of the sample are clearly covered in a higher thickness than the points located in the center of the substrate plate.

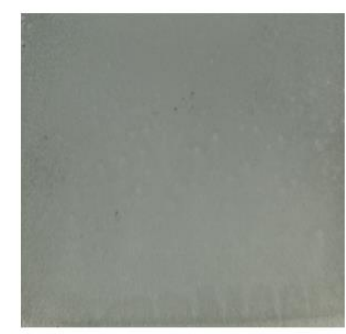

(a)

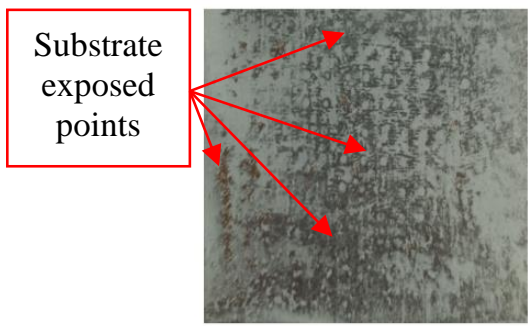

(d)

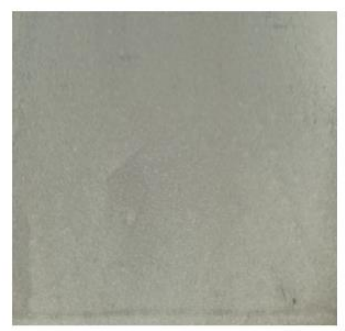

(b)

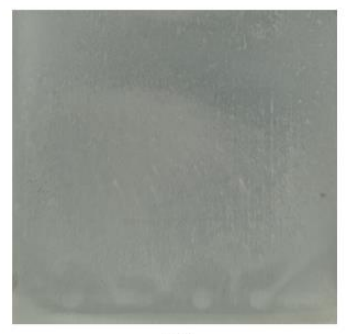

(e)

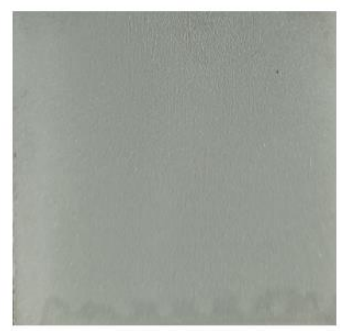

(c)

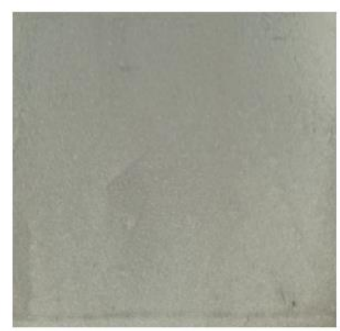

(f)

Figure 3: Images of the samples right after the electroplating process at $40{ }^{\circ} \mathrm{C}(\mathrm{a}), 50^{\circ} \mathrm{C}(\mathrm{b}), 60^{\circ} \mathrm{C}(\mathrm{c})$, $7.5 \mathrm{~mA} \cdot \mathrm{cm}^{-2}(d), 19.0 \mathrm{~mA} \cdot \mathrm{cm}^{-2}(e)$, and $30.5 \mathrm{~mA} . \mathrm{cm}^{-2}(f)$.

Analyzing the images (Figure 4) obtained by optical microscopy (OM) was possible to observe that the maximum temperature (Figure $4 \mathrm{c}$ ) evaluated changed the coating compactness. The samples obtained at $40{ }^{\circ} \mathrm{C}$ (Figure 4a) and $50{ }^{\circ} \mathrm{C}$ (Figure $4 \mathrm{~b}$ ) tended to present similar deposits appearance, suggesting higher uniformity. 


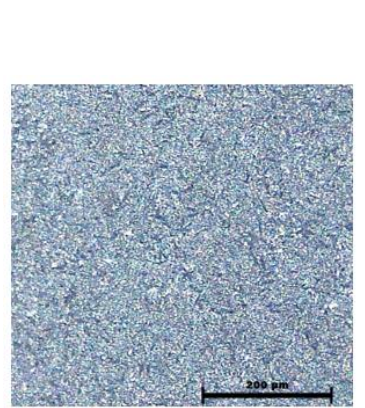

(a)

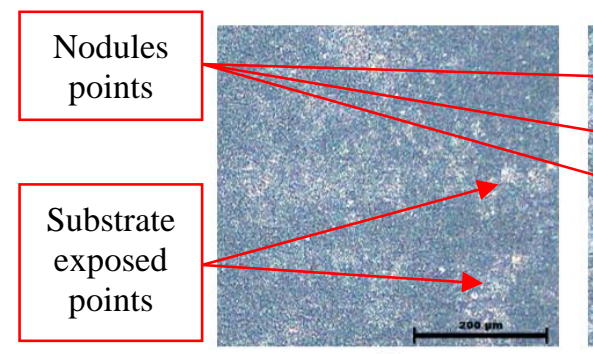

(d)

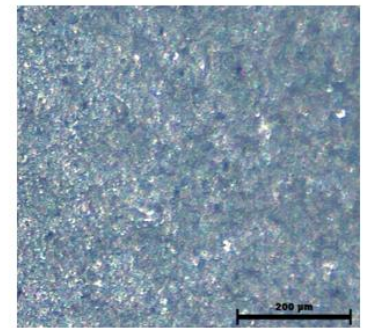

(b)

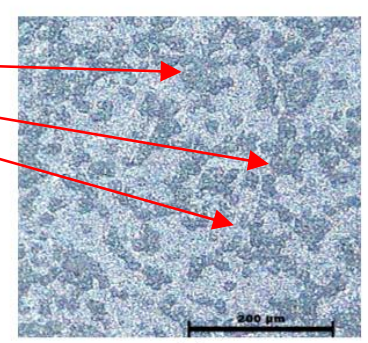

(e)

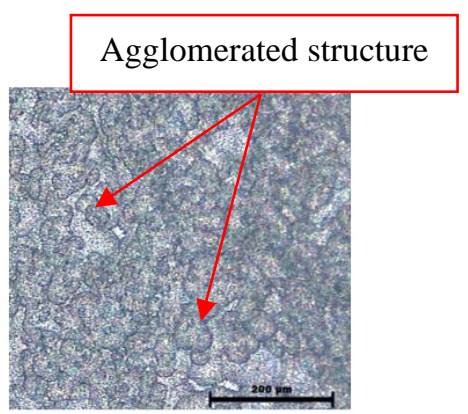

(c)

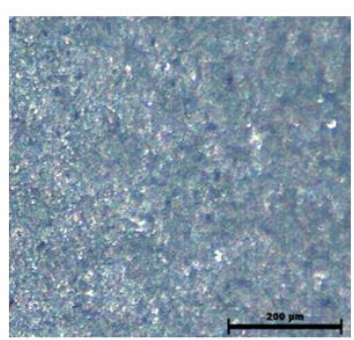

(f)

Figure 4: Images obtained by optical microscopy (OM) of the samples after the electroplating process at $40^{\circ} \mathrm{C}(\mathrm{a}), 50^{\circ} \mathrm{C}(b), 60^{\circ} \mathrm{C}(\mathrm{c}), 7.5 \mathrm{~mA} \cdot \mathrm{cm}^{-2}(d), 19.0 \mathrm{~mA} \cdot \mathrm{cm}^{-2}(e)$, and $30.5 \mathrm{~mA} \cdot \mathrm{cm}^{-2}(f)$.

The OM images to current density variation also evidence the substrate exposure at the sample obtained at $7.5 \mathrm{~mA} . \mathrm{cm}^{-2}$ (Figure 4d), while $19.0 \mathrm{~mA} \cdot \mathrm{cm}^{-2}$ (Figure 4e) apparently produced a full covered coating with agglomerated structures, resembling nodules. A compact and higher uniformity coating was noted at $30.5 \mathrm{~mA} . \mathrm{cm}^{-2}$ (Figure $4 \mathrm{f}$ ).

Through analysis of images obtained by SEM it is possible to observe that the samples obtained at $40{ }^{\circ} \mathrm{C}$ (Figure $5 \mathrm{a}$ and $5 \mathrm{~d}$ ) and $50{ }^{\circ} \mathrm{C}$ (Figure $5 \mathrm{~b}$ and 5e) presented a refined grain size, and a compact and homogeneous coating.

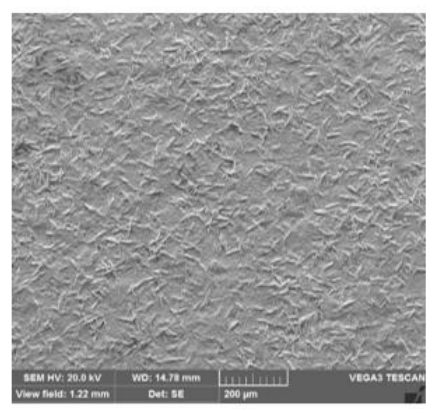

(a)

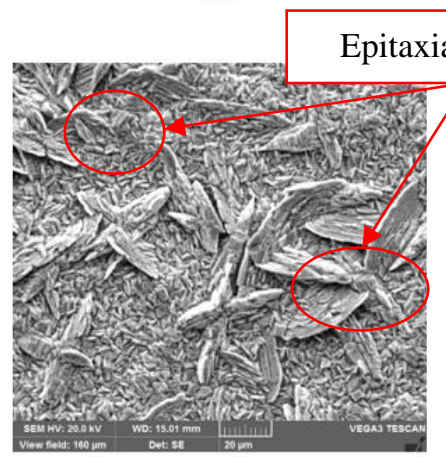

(d)

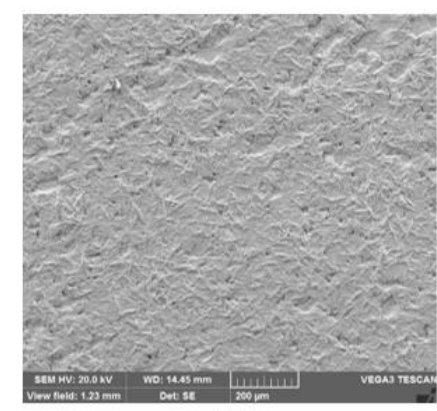

(b)

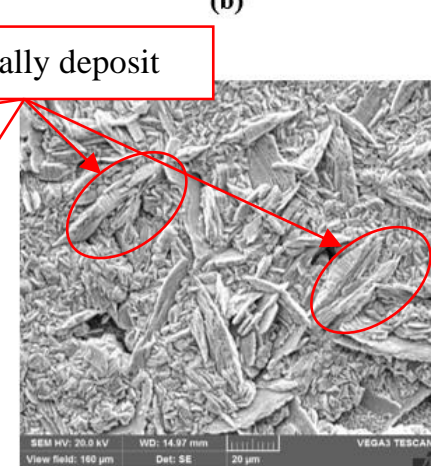

(e)
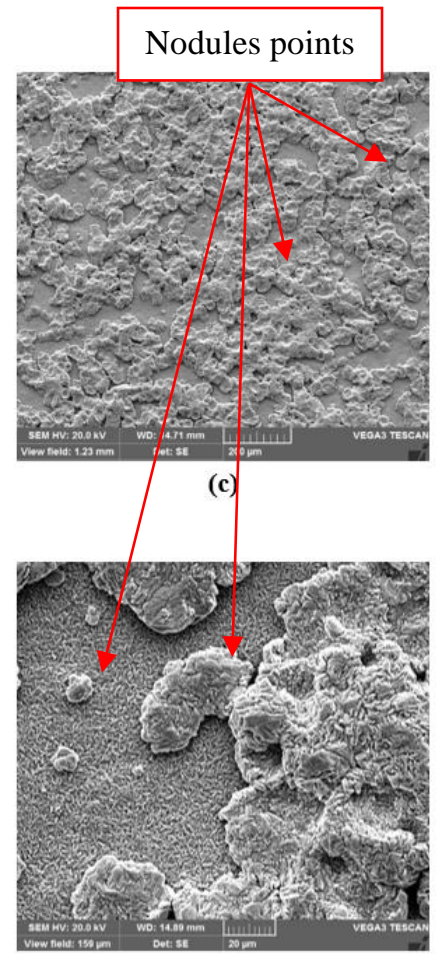

(f)

Figure 5: SEM images of the samples obtained varying the operational temperature: $40{ }^{\circ} \mathrm{C}(\mathrm{a})$ and $(\mathrm{d})$, $50^{\circ} \mathrm{C}(\mathrm{b})$ and $(e)$, and $60^{\circ} \mathrm{C}(\mathrm{c})$ and $(f)$. 
In the beginning, zinc is deposited epitaxially in layers over the substrate and then the grain starts to grow [20], as shown at Figures 5d and 5e. On the other wise, the sample obtained at $60{ }^{\circ} \mathrm{C}$ (Figures $5 \mathrm{c}$ and $5 \mathrm{f}$ ) presented nodules points and the absence of epitaxially deposits. This behavior suggests that the temperature impacts the zinc grain growth in the coating, and increasing the temperature, the surface roughness will tend to increase.

According to the literature as the temperature increases, the deposit surface indeed becomes rougher [14]. The temperature implies directly in the electrodeposition rate of zinc over the substrate, so, the authors recommends that the temperature does not exceed $45^{\circ} \mathrm{C}$. The deposition method of the zinc in the substrate surface directly impacts the coating's properties, such as gloss, roughness, and corrosion resistance [20].

Differently from what was observed in the temperature variation, the current density impacted significantly in the material quality, as shown in the SEM images in Figure 6. The sample obtained at $7.5 \mathrm{~mA} . \mathrm{cm}^{-2}$ (Figures 6a and 6d) did not cover the entire substrate surface. Despite covering all substrate surface, the samples obtained at $19.0 \mathrm{~mA} . \mathrm{cm}^{-2}$ resulted in a rougher surface due the presence of nodules (Figures $6 \mathrm{~b}$ and $6 \mathrm{e}$ ). Only the sample obtained at $30.5 \mathrm{~mA} . \mathrm{cm}^{-2}$ (Figures $6 \mathrm{c}$ and 6f) presented better deposit quality and a smooth coating.

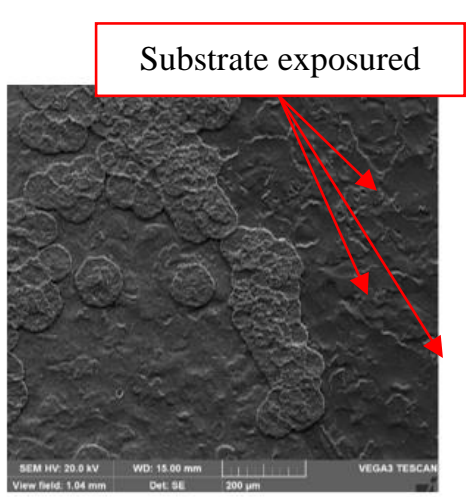

(a)

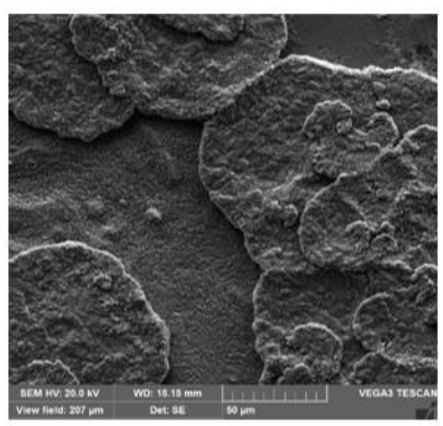

(d)
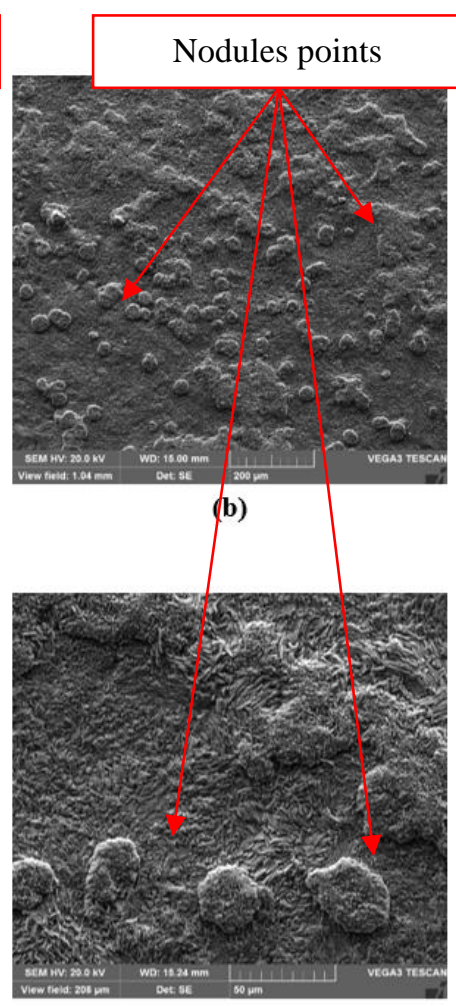

(e)

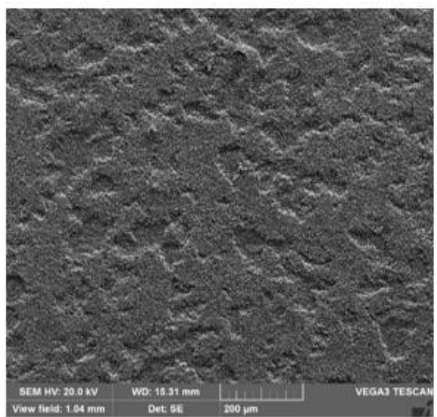

(c)

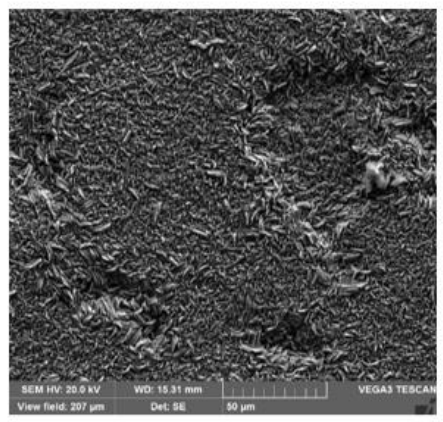

(f)

Figure 6: SEM images of the samples obtained varying the operational current density: $7.5 \mathrm{~mA} . \mathrm{cm}^{-2}$ (a) and $(d), 19.0 \mathrm{~mA} \cdot \mathrm{cm}^{-2}(b)$ and $(e)$, and $30.5 \mathrm{~mA} . \mathrm{cm}^{-2}(c)$ and $(f)$.

The variation of current density in the range evaluated $\left(7.5 \mathrm{~mA} \cdot \mathrm{cm}^{-2}\right.$ to $\left.30.5 \mathrm{~mA} \cdot \mathrm{cm}^{-2}\right)$ apparently impacted the refined grain size by increasing the nucleation rate as increasing the current density, as also reported in the literature. However, the authors warn that above the ideal value, identified experimentally, the current density promotes the deposit deterioration, such as porous coating with rough aspect.

Therefore, under the conditions evaluated and through the results of the tests presented, the samples obtained at $40{ }^{\circ} \mathrm{C}, 50{ }^{\circ} \mathrm{C}$, and $30 \mathrm{~mA} \cdot \mathrm{cm}^{-2}$ showed better performance and greater homogeneity and quality of the surface coating. 


\section{CONCLUSION}

The temperature variation $\left(40{ }^{\circ} \mathrm{C}, 50{ }^{\circ} \mathrm{C}\right.$, and $\left.60{ }^{\circ} \mathrm{C}\right)$ maintaining the current density at $30.5 \mathrm{~mA} . \mathrm{cm}^{-2}$ did not promote impacts on the current efficiency. The $e_{c}$ in all temperatures evaluated remained over $95 \%$, which classifies the process as efficient. On the other hand, increasing the current density $\left(7.5 \mathrm{~mA} . \mathrm{cm}^{-2}, 19.0 \mathrm{~mA} \cdot \mathrm{cm}^{-2}\right.$, and $\left.30.5 \mathrm{~mA} . \mathrm{cm}^{-2}\right)$ maintaining the temperature at $50{ }^{\circ} \mathrm{C}$ tended to increase the current efficiency, reaching from $(87 \pm 2) \%$ at $7.5 \mathrm{~mA} \cdot \mathrm{cm}^{-2}$ to $(95 \pm 1) \%$ at $30.5 \mathrm{~mA} \cdot \mathrm{cm}^{-2}$. In general, all samples had the arithmetic mean thickness of the coating greater than the theoretical thickness calculated. Such behavior could be attributed to the no equally distribution of the local electric field in the sample. Therefore, the coating thickness tends to be higher on the edges and corners than in the substrate center. Through the images for the surface characterization were possible to observe that the increase in the temperature tended to turn the coating rougher. The samples obtained at $40{ }^{\circ} \mathrm{C}$ and $50{ }^{\circ} \mathrm{C}$ tended to present a similar coating profile characterized by epitaxially deposits and refining grain size. The variation of current density impacts the surface morphology. Increasing the current density tended to increase the zinc refining grain size in the coating. It should be noted that at low current density $\left(7.5 \mathrm{~mA} . \mathrm{cm}^{-2}\right)$ the substrate surface was not homogeneous covered, exposing the substrate. The samples obtained at $19.0 \mathrm{~mA} . \mathrm{cm}^{-2}$ presented nodules adhered to the coating surface, while the samples obtained at $30.5 \mathrm{~mA} . \mathrm{cm}^{-2}$ presented a compact and smooth surface aspect. Therefore, we recommend the zinc electroplating in an acid sulfate-based solution at a temperature between $40{ }^{\circ} \mathrm{C}$ and $50{ }^{\circ} \mathrm{C}$ associated with a current density of $30.5 \mathrm{~mA} . \mathrm{cm}^{-2}$.

\section{ACKNOWLEDGMENT}

The authors would like to acknowledge to CAPES [Coordination for the Improvement of Higher Education Personnel (88887.495176/2020-00)], to the Federal University of Southern Bahia (UFSB, BA, BR), and to the Pro-Rectory of Research and Post-Graduation at State University of Santa Cruz (PROPP/UESC, BA, BR) for the financial support; to Usiminas S.A. by the AISI 1008 carbon steel; to Nexa Resources S.A. by the zinc; to Klintex Industrial Resources by the alkaline degreaser; to Nanotechnology Laboratory at Federal University of Ouro Preto (NanoLab/UFOP, MG, BR) and to Electrochemistry and Corrosion Laboratory at the Department of Chemical Engineering at the Polytechnique School of the University of São Paulo (LEC/DEQ/Poli-USP, SP, BR) by the scanning electron microscopy (SEM) and thickness measurements analysis; to the Center for Electron Microscopy of the State University of Santa Cruz (CME/UESC, BA, BR) by the optical microscopy analysis; to the Environmental and Materials Laboratory (LAMMA/UESC, BA, BR) by the support, inputs, and equipment that made this work possible.

\section{REFERENCES}

1. Da Luz FS, Pinheiro WA, Monteiro SN, Candido VS, Da Silva ACR. Mechanical properties and microstructural characterization of a novel 316L austenitic stainless steel coating on A516 Grade 70 carbon steel weld. J Mater Res Technol. 2020 Jan;9(1):636-40. doi: 10.1016/j.jmrt.2019.11.004

2. Zhang S, Hou L, Du H, Wei H, Liu B, Wei Y. A study on the interaction between chloride ions and $\mathrm{CO}_{2}$ towards carbon steel corrosion. Corros Sci. 2020 May;167(1):108531. doi: 10.1016/j.corsci.2020.108531

3. Shreir LL, Jarman RA, Burstein GT. Corrosion: Metal/Environment Reactions. 3rd ed. Oxford (UK): Butterworth-Heinemann; 2000.

4. Bonvicini S, Antonioni G, Cozzani V. Assessment of the risk related to environmental damage following major accidents in onshore pipelines. J Loss Prev Process Ind. 2018 Nov;56:505-16. doi: 10.1016/j.jlp.2018.11.005

5. Shin S, Lee G, Ahmed U, Lee Y, Na J, Han C. Risk-based underground pipeline safety management considering corrosion effect. J Haz Mat. 2018 Jan;342: 279-89. doi: 10.1016/j.jhazmat.2017.08.029

6. Rossi B, Marquart S, Rossi G. Comparative life cycle cost assessment of painted and hot-dip galvanized bridges. J Environ Manage. 2017 Jul;197:41-9. doi: 10.1016/j.jenvman.2017.03.022 
7. Karima H, Sameh B, Baya B, Louiza B, Soraya H, Hatem B, et al. Corrosion inhibition impact of Pyracantha coccinea M. Roem extracts and their use as additives in zinc electroplating: Coating morphology, electrochemical and weight loss investigations. J Taiwan Inst Chem Eng. 2021 Apr;121(2):337-48. doi: 10.1016/j.jtice.2021.04.007

8. Alshater AF, Hakeem AS, Saadi OW, Ezuber HM, Ebrahim A, Alhamri F, et al. A correlative study amongst overlay nanostructure and emanating corrosion behavior of pulse-electroplated nanocrystalline zinc on carbon steel. Appl Nanosci. 2019 Feb;9:289-304. doi: 10.1007/s13204-019-00982-x

9. Alvarenga EA, Lins VFC. Atmospheric corrosion evaluation of electrogalvanized, hot-dip galvanized and galvannealed interstitial free steels using accelerated field and cyclic tests. Surf Coatings Technol. 2016 Nov;306(Part B):428-38. doi: 10.1016/j.surfcoat.2016.04.021

10. Bai A, Yang K-L, Chen H-L, Hong Y-H, Chang S-B. High current density on electroplating smooth alkaline zinc coating. MATEC Web Conf. 2017 Dec;123(24):1-7. doi: $10.1051 /$ matecconf/201712300024

11. Hsieh J-C, Hu C-C, Lee T-C. The synergistic effects of additives on improving the electroplating of zinc under high current densities. J Electrochem Soc. 2008 Aug;155(10):675-81. doi: $10.1149 / 1.2967343$

12. Paunovic M, Schlesinger M. Fundamentals of electrochemical deposition. 2. ed. New Jersey (NJ): John Wiley \& Sons, Inc.; 2006.

13. Almeida MDJ, Rovere CAD, Lima LRPA, Ribeiro DV, De Souza CAC. Glycerol effect on the corrosion resistance and electrodeposition conditions in a zinc electroplating process. Mater Res. 2019 Jun;22(4):1-13. doi: 10.1590/1980-5373-MR-2018-0480

14. Scott AC, Pitblado RM, Barton GW, Ault AR. Experimental determination of the factors affecting zinc electrowinning efficiency. J Appl Electrochem. 1988 Jan;18(1):120-7. doi: 10.1007/BF01016215

15. Jung S-M, Cho Y-M, Na H-G. Chemical analysis of zinc electroplating solutions by X-ray fluorescence spectrometry. Iron Steel Inst Japan Int. 2007 Jul;47(6):853-9. doi: 10.2355/isijinternational.47.853

16. Loto CA. Electrodeposition of Zinc from acid based solutions: A review and experimental study. Asian J Appl Sci. 2012 Aug;5(6):314-26. doi: 10.3923/ajaps.2012.314.326

17. Pan J, Wen Y, Cheng J, Pan J, Bai Z, Yang Y. Zinc deposition and dissolution in sulfuric acid onto a graphiteresin composite electrode as the negative electrode reactions in acidic zinc-based redox flow batteries. J Appl Electrochem. 2013 Mar;43:541-51. doi: 10.1007/s10800-013-0538-1

18. Muralidhara HB, Naik YA, Venkatesha T V. Effect of condensation product of glycyl-glycine and furfural on electrodeposition of zinc from sulphate bath. Bull Mater Sci. 2006 Oct;29(5):497-503. doi: 10.1007/BF02914081

19. Wark IW. The electrodeposition of zinc from acidified zinc sulphate solution. J Appl Electrochem. 1979 Nov;9:721-30. doi: 10.1007/BF00614966

20. Nakano H. Effects of plating factors on morphology and appearance of electrogalvanized steel sheets. Trans Nonferrous Met Soc China. 2009 Aug;19(4):835-41. doi: 10.1016/S1003-6326(08)60360-X

21. Park H, Szpunar JA. The role of texture and morphology in optimizing the corrosion resistance of zincbased electrogalvanized coatings. Corros Sci. 1998 Apr;40(4-5):525-45. doi: 10.1016/S0010938X(97)00148-0

22. Wu L, Ashworth MA, Wilcox GD. The role of nodules in the growth of Zn whiskers from alkaline cyanide-free Zn electrodeposits. ECS Trans. 2015 Nov;66(1):1-9. doi: 10.1149/06621.0001ecst

23. Kul M, Oskay KO, Erden F, Akça E, Katirci R, Köksal E, et al. Effect of process parameters on the electrodeposition of zinc on 1010 steel: Central composite design optimization. Int J Electrochem Sci. 2020 Oct;15:9779-95. doi: 10.20964/2020.10.19

24.Zhang QB, Hua YX, Dong TG, Zhou DG. Effects of temperature and current density on zinc electrodeposition from acidic sulfate electrolyte with [BMIM] $\mathrm{HSO}_{4}$ as additive. J Appl Electrochem. 2009 Jan;39:1207-16. doi: 10.1007/s10800-009-9786-5 